\title{
GFFECT OF LIME-PHOSPHORUS AND GREEN MANURE ON SWEET POTATOES AND CORN GROWN IN ACID SOILS
}

\author{
By J. A. Bonnet, P. Tirado Sulsona and F. Abruña ${ }^{1}$
}

\section{INTRODUCTION}

In general, the yields of food crops that grow in the acid soils of the humid area of Puerto Rico, have been low because no attention has been given to the correction of soil deficiencies. It was of importance, therefore, to obtain data of their yields when lime, phosphorus and green manure were added to these acid soils.

The effect of lime and phosphorus added to two acid soils in Puerto Rico was studied on the yields of seven crops in a rotation sequence of green manure, green manure, sweet potatoes, green manure, green manure, corn and corn, in a three-year period from May 1944 to August 1947 at two locations, Río Piedras and Mayagüez.

Each crop of green manure included four leguminosae; velvet beans Stizolobium deeringianum, crotalaria Crotalaria striata, cowpeas Vigna sinensis, and soybeans Soja max, Otootan variety. Data for the first two crops of the four leguminosae have been reported by Bonnet et al. (1). The combined experiments at Río Piedras and Mayagüez, excluding the crotalaria because of its poor growth in Mayagüez, had indicated that:

"1. The mean dry-matter yield of velvet beans in the presence or absence of the lime and phosphorus application or as a whole, was significantly higher at the 1 per cent point, than that of cowpeas and soybeans; whereas that of cowpeas was higher than that of soybeans.

“2. The mean dry-matter yield of velvet beans with lime and phosphorus, was significantly higher at the 1 per cent point, than that of velvet beans without lime and phosphorus. The same applies to soybeans, and cowpeas."

${ }^{1}$ Respectively, Head Dept. of Soils, and two Jr. Soil Conservationists. This work was undertaken in cooperation with the Soil Conservation Service of Puerto Rico, of which Mr. E. A. Telford, Assoc. Soil Conservationist was in charge of the field experiments at Mayaguiez, and with the Federal Experiment Station that provided land and office spaco at Mayagüez. 
The combined experiments at Río Piedras, including the crotalaria had indicated that:

- "1. The mean dry-matter yield of velvet beans in the presence or absence of lime and phosphorus applications or as a whole, was significantly higher at the 1 per cent point, than that of cowpeas, soybeans and crotalaria; whereas that of cowpeas was higher than that of soybeans, and crotalaria. The soybeans yield was significantly higher at the 5 per cent point, than that of the crotalaria, in the absence of lime and phosphorus, and significantly lower in their presence; but as a whole there was no significant mean difference between them.

"2. The velvet beans, soybeans and crotalaria, responded significantly at the 1 per cent point, to the application of lime and phosphorus. The cowpeas showed no response to the fertilizer.

"3. Velvet beans, the highest yielder, gave for both locations, in the absence or presence of lime and phosphorus, mean green matter of 83.5 and 110.0 hundredweights per acre, respectively. This is equivalent to mean dry-matter of 17.4 and 22.6 hundredweights per acre."

Results obtained with the other five crops in the rotation, sweet potatoes, green manure, green manure, corn and corn are reported in this paper.

\section{Procedure}

Location.-The two locations where the experimental fields were established are within the humid section; Río Piedras at the North of Puerto Rico on $18^{\circ}-24^{\prime} \mathrm{N}$. latitude and $63^{\circ}-03^{\prime} \mathrm{W}$. longitude and Mayagüez at the West on $18^{\circ}-12^{\prime} \mathrm{N}$. latitude and $67^{\circ}-09^{\prime} \mathrm{W}$. longitude. The linear distance between both locations is 120 kilometers or 74.5 miles.

Soils.-Two one-acre fields of the soil type Fajardo clay, at the Experiment Station farm in Río Piedras, and two of Catalina clay level phase, at Las Ochenta farm in Mayagüez, were chosen for the sites of the experiment. Two fields were chosen at each place to study also the effect of two methods of incorporating green manure on the crop yield of sweet potatoes and corn. In field " $\mathrm{A}$ " the green manure was turned-under with a hoe, as done by small farmers and in field " $\mathrm{B}$ " it was plowed under with a tractor-driven plow, as done by the large landowners. Fajardo clay is a red soil derived from ashy shales. 
Catalina clay level phase is a lateritic soil derived from andesitic tuff and tuffaceous shale. The total base exchange capacity of Fajardo clay is between 14 and 22 mili-equivalents per 100 grams of soil and that of Catalina clay between 8 and 14 .

Crop Rotation and Treatment.-The crop rotation sequence, the dates of planting, and the mean age at harvest, for each crop, are reported in table 1 .

TABLE NO. I

ROTATION SEQUENCE, PLANTING DATES AND AGE OF CROPS AT RIO PIEDRAS AND MAYAGUEZ

\begin{tabular}{|c|c|c|c|c|}
\hline Rotation Sequence & Crop & Location & Date of Planting & $\begin{array}{l}\text { Mean Age } \\
\text { at Harvest }\end{array}$ \\
\hline THIRD & Sweet potatoes & $\begin{array}{l}\text { Río Piedras } \\
\text { Mayagüez }\end{array}$ & $\begin{array}{c}1945 \\
\text { Feb. } 1-5 \ldots \ldots \ldots \ldots \ldots \ldots \ldots \ldots \ldots \ldots \ldots \\
\text { April } 1-7 \ldots \ldots \ldots \ldots \ldots \ldots\end{array}$ & $\begin{array}{l}\text { DAYS } \\
\qquad \begin{array}{r}142 \\
168\end{array}\end{array}$ \\
\hline Fotrth & $\begin{array}{l}\text { Velvet beans } \\
\text { Crotalaria } \\
\text { Cowpeas } \\
\text { Soybeans } \\
\text { Velvet Beans } \\
\text { Crotalaria } \\
\text { Cowpeas } \\
\text { Soybeans }\end{array}$ & $\begin{array}{l}\text { Río Piedras } \\
\text { Mayagüez }\end{array}$ & 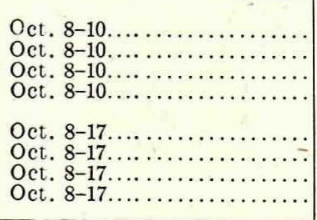 & $\begin{array}{l}\varepsilon 6 \\
86 \\
57 \\
57 \\
84 \\
87 \\
59 \\
59\end{array}$ \\
\hline Fifth & $\begin{array}{l}\text { Velvet beans } \\
\text { Crotala-ia } \\
\text { Cowpeas } \\
\text { Soybeans } \\
\text { Velvet beans } \\
\text { Crotalaria } \\
\text { Cowpeas } \\
\text { Soybeans }\end{array}$ & $\begin{array}{l}\text { Río Piedras } \\
\text { Mayagïez }\end{array}$ & 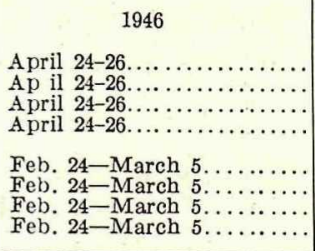 & $\begin{array}{r}82 \\
82 \\
60 \\
60 \\
\\
103 \\
87 \\
66 \\
66\end{array}$ \\
\hline SIXTH & Corn & $\begin{array}{l}\text { Río Piedras } \\
\text { Mayagüez }\end{array}$ & $\begin{array}{l}\text { Sept. } 5-8, \ldots \ldots \ldots \ldots \ldots \ldots \ldots \\
\text { August } 8-10 \ldots \ldots \ldots \ldots \ldots \ldots\end{array}$ & $\begin{array}{r}102 \\
91\end{array}$ \\
\hline SEVENTH & Corn & $\begin{array}{l}\text { Río Piedras } \\
\text { Mayagïez }\end{array}$ & $\begin{array}{c}1947 \\
\text { April } 28 \ldots \ldots \ldots \ldots \ldots \ldots \ldots \ldots \\
\text { May } 15-20 \ldots \ldots \ldots \ldots \ldots \ldots\end{array}$ & $\begin{array}{r}100 \\
91\end{array}$ \\
\hline
\end{tabular}

Sweet potato (Ipomea Batatas Don Juan variety) cuttings, about 12 to 14 inches long, were planted at the .rate of two per hole, with an 18-inch separation between holes and with a threefoot distance between rows. The potatoes were dug out and the trash was left over each respective plot.

The leguminosae were planted at a one-foot distance between rows. The distance between plants for the velvet beans was six 
inches and for the cowpeas and soybeans was four inches. The crotalaria seeds were planted continuously within the row.

The corn (Zea Mays Mayorbela variety) was planted at a three-foot distance between rows and at eighteen inches between plants within the row. Four corn seeds were placed in each hole and after germination two plants were left at each hole. The crop was sprayed with lead arsenate, at the rate of threepounds per 100 gallons of water, for the control of the leaf worm Laphygma frugiperda. Rats were kept under control using a bait of phosphorus paste with corn flour or with pieces of ripe bananas. The corn trash was left over each respective plot.

Half of the plots in each field received limestone at the rate of four tons per acre and superphosphate at the rate of 100 pounds $\mathrm{P}_{2} \mathrm{O}_{5}$ per acre. The limestone was broadcast and the phosphorus was applied in the row. For the second corn crop, (the seventh crop) half of the plots in each field received a second application of superphosphate at the rate of 100 pounds $\mathrm{P}_{2} \mathrm{O}_{5}$ per acre as well as muriate of potash at the rate of 240 pounds $\mathrm{K}_{2} \mathrm{O}$ per acre. Half of the checks of this corn crop received ammonium sulphate at the rate of 250 pounds $\mathrm{NH}_{3}$ per acre.

After the first corn crop (the sixth in the rotation) was harvested, soil samples were taken at a depth of four inches from each plot in each of the two fields at both locations and were analyzed for $\mathrm{pH}$, organic matter, nitrates and available phosphorus. Total nitrogen was determined in the composite samples for each treatment at each field in both locations. The lata are reported in table 8 .

The organic matter was determined by the rapid colorimetric method using the Cenco Wilde organic matter color scale No. 28303, sold and explained by Central Scientific Co., Chicago. The nitrates and available phosphorus were determined, as per Wolfe's (2), extracting with Morgan's solution of normal sodium acetate, buffered at $\mathrm{pH} 4.8$, with acetic acid.

\section{Experimental Data}

The yields at Río Piedras and Mayagüez, for the crop sequence sweet potatoes, green manure, green manure, corn and corn, are reported in tables 2,4 and 5, respectively. The columns "mulched and hoed" correspond to fields " $\mathrm{A}$ " and those 
for "turned under" correspond to fields " $\mathrm{B}$ ". The symbols Ca, $\mathrm{P}, \mathrm{N}$ and $\mathrm{K}$ refer to calcium, phosphorus, nitrogen and potas- . sium, respectively.

\section{Statistical Interpretation}

The Sweet Potato Crop.-The acre yields in hundredweights of sweet potatoes with the different green manure and fertilizer treatments, are given in table 2. Data are reported separately for the crops grown at Río Piedras and Mayagüez and for each field where the green manure was either mulched and hoed or plowed under the soil.

The analysis of the total sum of squared deviations for the combined crops of sweet potatoes harvested at Río Piedras and Mayagüez is given in table 3 .

There is a highly significant difference in the mean yields of sweet potatoes between locations. The acre mean yield of sweet potatoes in the untreated plots at Río Piedras was 98.4 hundredweights and in Mayagüez was 40.8. The mean acre yield of sweet potatoes in the plots that received lime and phosphorus at Río Piedras was 122.8 hundredweights and in Mayagüez was 63.2. In both locations, the increases in yields of sweet potatoes, due to lime and phosphorus, were highly significant (tables $2,3)$.

TABLE NO. II

YIELDS IN HUNDREDWEIGHTS OF SWEET POTATOES TO THE ACRE, WITH THE DIFFERENT GREEN MANURE AND FERTILIZER TREATMENTS.

\begin{tabular}{|c|c|c|c|c|c|c|}
\hline \multirow[b]{2}{*}{ Treatments } & \multicolumn{2}{|c|}{ Rio Piedras } & \multicolumn{2}{|c|}{ Mayaguez } & \multirow[b]{2}{*}{$\begin{array}{l}\text { Treat- } \\
\text { ments }\end{array}$} & \multirow[b]{2}{*}{ General } \\
\hline & $\begin{array}{l}\text { Mulched } \\
\text { and Hoed }\end{array}$ & $\begin{array}{l}\text { Plowed } \\
\text { Under }\end{array}$ & $\begin{array}{l}\text { Mulched } \\
\text { and Hoed }\end{array}$ & $\begin{array}{l}\text { Plowed } \\
\text { Under }\end{array}$ & & \\
\hline 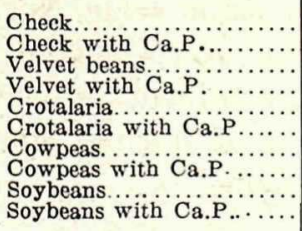 & $\begin{array}{r}103.6 \\
124.4 \\
119.9 \\
136.0 \\
126.7 \\
129.7 \\
74.3 \\
101.0 \\
89.2 \\
120.2\end{array}$ & $\begin{array}{r}109.7 \\
129.7 \\
116.8 \\
146.6 \\
110.2 \\
128.0 \\
55.6 \\
91.4 \\
78.3 \\
121.2\end{array}$ & $\begin{array}{l}47.1 \\
56.9 \\
44.4 \\
71.3 \\
49.5 \\
55.1 \\
37.6 \\
64.4 \\
25.4 \\
57.5\end{array}$ & $\begin{array}{l}38.1 \\
61.5 \\
58.7 \\
87.1 \\
38.9 \\
60.7 \\
28.9 \\
58.5 \\
39.7 \\
\mathbf{5 8 . 8}\end{array}$ & $\begin{array}{r}74.6 \\
93.1 \\
85.1 \\
110.3 \\
81.3 \\
93.4 \\
49.1 \\
78.8 \\
58.2 \\
89.4\end{array}$ & $\begin{array}{l}97.7 \\
87.4\end{array}$ \\
\hline \multicolumn{5}{|c|}{ 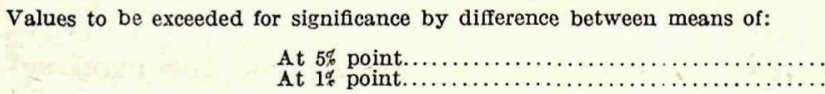 } & 12.5 & $\begin{array}{r}8.8 \\
11.6\end{array}$ \\
\hline
\end{tabular}

The yields of sweet potatoes planted in the velvet beans plots were significantly higher than in the cowpeas, soybeans and 
check plots. The cowpeas showed a highly significant detrimental effect in the yield of sweet potatoes; the cowpeas plots gave 64.0 hundredweights to the acre while the checks gave 83.9 (table 2).

There was no significant difference in the yields of sweet potatoes between the fields (table 3 ) at both locations when the green manure was either mulched and hoed or plowed under the soil. However, there was a highly significant difference between location, species, and lime-phosphorus treatment. There was also a highly significant interaction of species $\mathrm{x}$ lime-phosphorus, of species $\mathrm{x}$ location, of species $\mathrm{x}$ fields and of lime-phosphorus $\mathrm{x}$ fields.

TABLE No. III

ANALYSES OF THE TOTAL SUM OF SQUARED DEVIATIONS FOR THE CROPS OF SWEET POTATOES AT RIO PIEDRAS AND MAYAGUEZ

\begin{tabular}{|c|c|c|c|c|c|}
\hline Source & $\begin{array}{c}\text { Degrees } \\
\text { of }\end{array}$ & Sum of & Variance & \multicolumn{2}{|c|}{$\mathrm{F}$-Values } \\
\hline 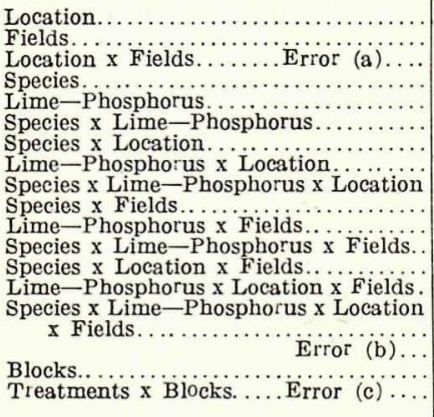 & $\begin{array}{c}1 \\
1 \\
1 \\
4 \\
1 \\
4 \\
4 \\
1 \\
4 \\
4 \\
1 \\
4 \\
(4) \\
(1) \\
(4) \\
9 \\
32 \\
288\end{array}$ & $\begin{array}{r}408,716 \\
50 \\
761 \\
47,779 \\
48,927 \\
4,766 \\
16,613 \\
83 \\
773 \\
4,235 \\
1,123 \\
632 \\
(1,191) \\
(191) \\
(954) \\
2,336 \\
153,963 \\
207,949\end{array}$ & $\begin{array}{r}408,716 \\
50 \\
761 \\
11,945 \\
48,927 \\
1,192 \\
4,153 \\
83 \\
193 \\
1,059 \\
1,123 \\
158 \\
(298) \\
(191) \\
(239) \\
260 \\
722\end{array}$ & $\begin{array}{r}537.1^{* *} \\
.1 \\
\ldots \ldots .9 * * \\
45.9 * 2^{* *} \\
188.6^{* *} \\
46.0^{* * *} \\
.3 \\
.7 \\
4.1^{* * *} \\
4.3^{*} \\
.6 \\
1.2 \\
.7 \\
.9 \\
\ldots \ldots . . . \\
\ldots \ldots . . .\end{array}$ & $\begin{array}{c}16.5^{* *} \\
67.8^{* *} \\
1.7\end{array}$ \\
\hline
\end{tabular}

Error (b)-For conclusions applicable to varying soil and climatic conditions in Puerto Rico.

Error (c)-For comparisons with a location. Used in last F-Column.

The Legume Crops.-The green manure and the dry yields of the fourth and fifth crops including velvet beans, crotalaria, cowpeas and soybeans, with or without lime and phosphorus at Río Piedras and Mayagüez, are reported in table 4.

The four leguminosae responded in a highly significant way to the application of lime and phosphorus. Among them, velvet beans gave the highest yield. Similar results were obtained previously by Bonnet et al (1). The mean green weight for the two crops of velvet beans, at both fields in Río Piedras and Mayagüez, was 74.7 hundredweights to the acre for the un- 
treated plots and 100.5 for the plots that received lime and phosphorus. On the basis of dry weight the respective values were 17.7 and 24.4 hundredweights.

TABLE No. IV

ACRE YIELDS IN HUNDREDWEIGHTS OF THE FOURTH AND FIFTE CROPS, THE TWO CONSECUTIVE LEGUMINOSAE CROPS WITH THE DIFFERENT FERTILIZER TREATMENTS

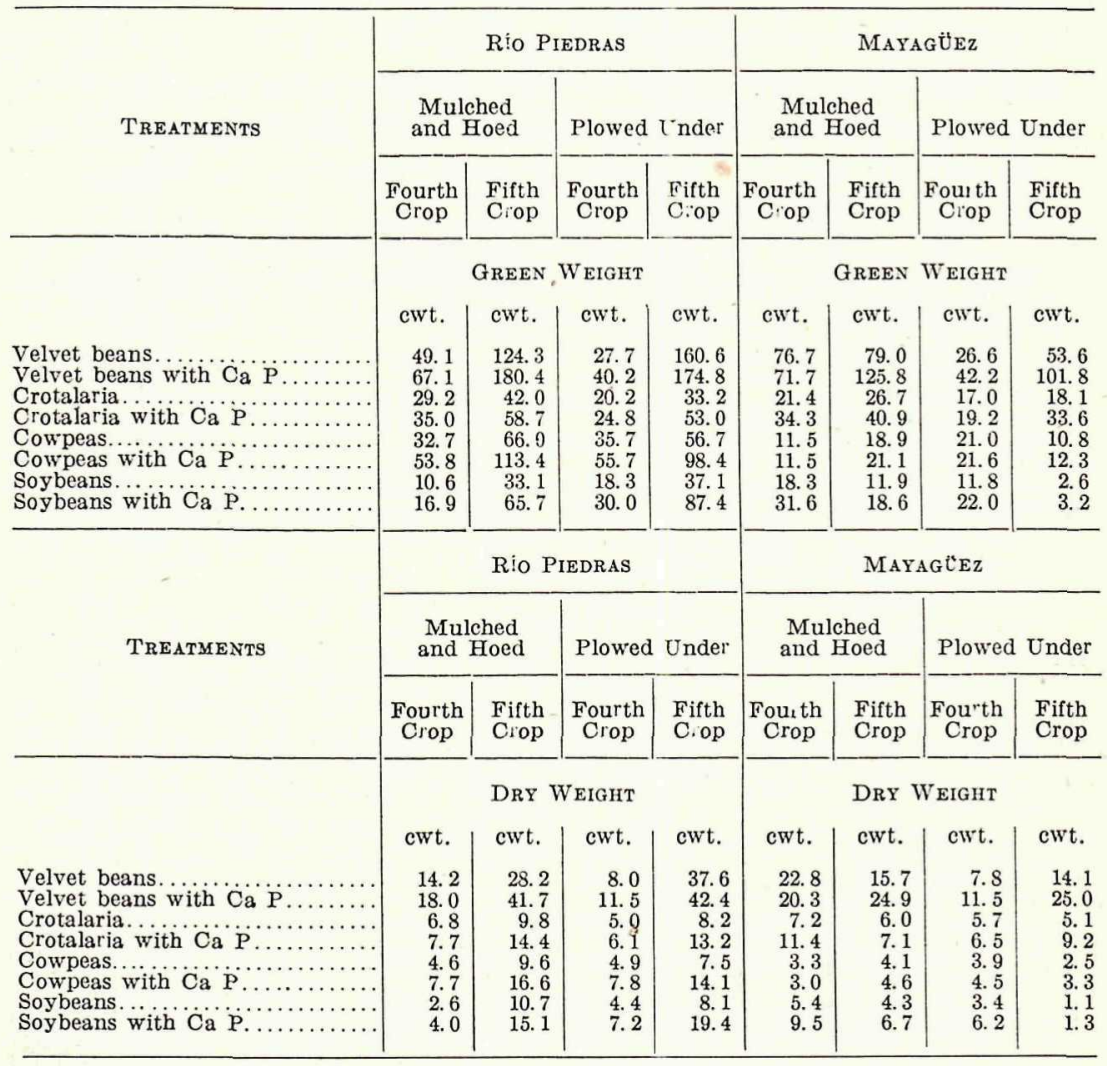

The Corn Crops.-The shelled corn yields in hundredweights to the acre, of the sixth crop in the rotation with the different green manure and fertilizer treatments at both fields, in Río Piedras and Mayagüez are given in table 5. The data were analyzed for each field and for both fields at each location.

There was a highly significant response of corn yields to the applications of lime and phosphorus (table 5, photos 1, 2, $5)$. The yields at Río Piedras were higher. At both locations the green manure from velvet beans that received lime and phos- 
phorus gave the highest significant increases in corn yields over those of the corresponding checks (photos 2, 3, 4, 5). In general, the corn yields obtained in the velvet beans plots were the highest. The mean acre yield of shelled corn for the velvet beans treatment in both fields at Río Piedras were 24.6 and 17.1 hundredweights, with and without lime and phosphorus, respectively. These yields correspond to 41 and 28.5 bushels

TABle No. V

ACRE YIELDS OF SHELLED CORN IN HUNDREDWEIGHTS FOR THE SIXTH CROP WITH THE DIFFERENT GREEN MANURE AND FERTILIZER TREATMENTS

\begin{tabular}{|c|c|c|c|c|}
\hline \multirow{2}{*}{ TREATMENTS } & \multicolumn{2}{|c|}{ Rfo PIEDRAS } & \multicolumn{2}{|c|}{ MAYAGUEZ } \\
\hline & $\begin{array}{l}\text { Mulched } \\
\text { and Hoed }\end{array}$ & $\begin{array}{l}\text { Plowed } \\
\text { Under }\end{array}$ & $\begin{array}{l}\text { Mulched } \\
\text { and Hoed }\end{array}$ & $\begin{array}{l}\text { Plowed } \\
\text { Under }\end{array}$ \\
\hline 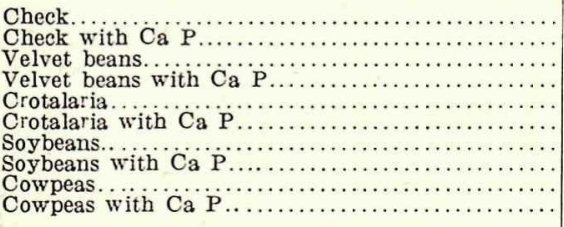 & $\begin{array}{l}11.7 \\
17.0 \\
15.3 \\
24.7 \\
14.7 \\
20.8 \\
10.6 \\
22.0 \\
15.9 \\
24.4\end{array}$ & $\begin{array}{r}10.5 \\
19.2 \\
18.9 \\
24.4 \\
13.4 \\
19.1 \\
10.7 \\
21.8 \\
9.8 \\
20.6\end{array}$ & $\begin{array}{r}1.6 \\
6.1 \\
6.2 \\
13.3 \\
2.3 \\
8.1 \\
3.4 \\
8.2 \\
2.5 \\
7.7\end{array}$ & $\begin{array}{r}1.7 \\
9.7 \\
4.3 \\
17.9 \\
3.1 \\
11.5 \\
3.4 \\
10.2 \\
1.7 \\
10.7\end{array}$ \\
\hline $\begin{array}{l}\text { Values to be exceeded for significance by difference } \\
\text { between treatments: } \\
\text { At } 5 \% \text { point } \ldots \ldots \ldots \ldots \ldots \ldots \ldots \ldots \ldots \ldots \ldots \ldots \ldots \ldots \ldots \ldots \ldots \ldots \ldots \ldots \ldots \ldots \ldots \ldots \ldots \\
\text { At } 1 \% \text { point } \ldots \ldots \ldots \ldots \ldots \ldots \ldots\end{array}$ & $\begin{array}{l}5.7 \\
7.5\end{array}$ & $\begin{array}{l}4.7 \\
6.3\end{array}$ & $\begin{array}{l}4.8 \\
3.6\end{array}$ & $\begin{array}{l}3.6 \\
4.8\end{array}$ \\
\hline
\end{tabular}

of corn, respectively. At Mayagüez, the green manure from velvet beans that received lime and phosphorus gave the highest significant increases in corn yields over those of the other three sources, but at Río Piedras, there was no significant difference between them.

The acre yields of shelled corn, in hundredweights, for the seventh and last crop in the rotation, with the different green manure and fertilizer treatments at both fields in Río Piedras and Mayagüez, are reported in table 6. The analysis for the total sum of squared deviations for this crop at both locations is reported in table 7 . 
TABLE No. VI

ACRE YIELDS OF SHELLED CORN IN HUNDREDWEIGHTS FOR THE SEVENTH CROP WITH THE DIFFERENT GREEN MANURE \& FERTILIZER TREATMENTS

\begin{tabular}{|c|c|c|c|c|c|c|}
\hline \multirow{2}{*}{ Treatments } & \multicolumn{2}{|c|}{ Rio PIEDRAS } & \multicolumn{2}{|c|}{ MAYAGtEZ } & \multirow{2}{*}{ Treatments } & \multirow[b]{2}{*}{ Genera } \\
\hline & $\begin{array}{l}\text { Mulched } \\
\text { and Hoed }\end{array}$ & $\begin{array}{l}\text { Plowed } \\
\text { Under }\end{array}$ & $\begin{array}{l}\text { Mulched } \\
\text { and Hoed }\end{array}$ & $\begin{array}{l}\text { Plowed } \\
\text { Under }\end{array}$ & & \\
\hline 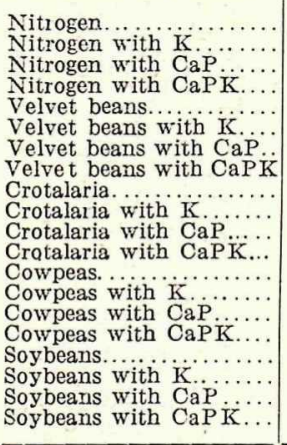 & $\begin{array}{r}11.3 \\
4.5 \\
16.9 \\
12.8 \\
6.3 \\
6.1 \\
12.1 \\
15.7 \\
8.0 \\
4.9 \\
11.7 \\
15.5 \\
7.4 \\
9.1 \\
16.3 \\
13.0 \\
2.5 \\
6.3 \\
11.3 \\
13.1\end{array}$ & $\begin{array}{r}6.6 \\
6.1 \\
14.9 \\
15.5 \\
10.2 \\
4.7 \\
8.2 \\
13.1 \\
9.2 \\
4.1 \\
14.2 \\
9.8 \\
4.1 \\
5.9 \\
11.8 \\
14.0 \\
7.4 \\
3.6 \\
15.3 \\
12.0\end{array}$ & $\begin{array}{r}6.0 \\
21.0 \\
15.9 \\
35.6 \\
11.6 \\
9.4 \\
21.9 \\
20.3 \\
9.7 \\
8.4 \\
23.9 \\
13.4 \\
6.6 \\
11.0 \\
13.5 \\
19.9 \\
9.8 \\
8.4 \\
18.6 \\
20.2\end{array}$ & $\begin{array}{r}1.2 \\
5.4 \\
6.3 \\
25.1 \\
4.0 \\
1.8 \\
8.8 \\
16.0 \\
3.8 \\
2.7 \\
8.9 \\
13.8 \\
4.7 \\
2.5 \\
11.4 \\
12.3 \\
3.2 \\
1.2 \\
9.5 \\
18.1\end{array}$ & $\begin{aligned} 6.2(8) * \\
8.8(10) \\
13.5(8) \\
22.3(10) \\
7.9(8) \\
5.4(10) \\
12.4(8) \\
15.6(10) \\
7.5(8) \\
4.9(10) \\
14.3(8) \\
12.6(10) \\
5.5(8) \\
7.0(10) \\
12.8(8) \\
14.3(10) \\
5.6(8) \\
4.8(10) \\
13.3(8) \\
15.1(10)\end{aligned}$ & $\begin{array}{l}9.8 \\
9.9\end{array}$ \\
\hline $\begin{array}{r}\text { Values to be exceeded for } \\
\text { At } 5 \% \text { point. } \\
\text { At } 1 \% \text { point... }\end{array}$ & gnificanc & - & - & & $\begin{array}{l}4.32(16) \\
4.08(18) \\
3.87(20) \\
5.70(16) \\
5.38(18) \\
5.10(20)\end{array}$ & $\begin{array}{l}1.99(72) \\
2.69(72)\end{array}$ \\
\hline
\end{tabular}

* Number of replicates.

TABLE No. VII

ANALYSES OF THE TOTAL SUM OF SQUARE DEVIATIONS FOR THE LAST CORN CROPS AT RIO PIEDRAS AND MAYAGUEZ

\begin{tabular}{|c|c|c|c|c|c|}
\hline Source & $\begin{array}{l}\text { Degrees } \\
\text { of } \\
\text { Freelom }\end{array}$ & $\begin{array}{l}\text { Sum of } \\
\text { Squares }\end{array}$ & Variance & \multicolumn{2}{|c|}{$\mathrm{F}$-Values } \\
\hline 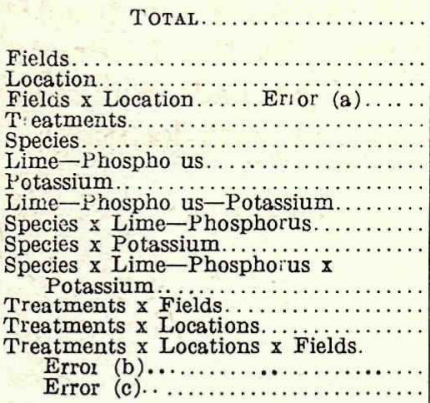 & $\begin{array}{r}359 \\
1 \\
1 \\
1 \\
(19) \\
4 \\
1 \\
1 \\
1 \\
4 \\
4 \\
4 \\
19 \\
19 \\
19 \\
280\end{array}$ & $\begin{array}{r}22,552 \\
1,333 \\
421 \\
828 \\
(9,140) \\
635 \\
7,076 \\
154 \\
257 \\
205 \\
646 \\
167 \\
354 \\
4,099 \\
4,687 \\
1,691\end{array}$ & $\begin{array}{r}1,333 \\
421 \\
828 \\
(481) \\
159 \\
7,076 \\
154 \\
257 \\
51 \\
161 \\
42 \\
19 \\
216 \\
\\
247 \\
6\end{array}$ & $\begin{array}{c}1.6 \\
.5 \\
2.0 \\
.6 \\
28.7 * * \\
.6 \\
1.0 \\
.2 \\
.7 \\
.2 \\
.1 \\
.9\end{array}$ & $\begin{array}{r}\text { 79. } 6^{* *} \\
26.3^{* *} \\
\text { 1, 171. } 6^{* *} \\
25.5^{* *} \\
42.6^{* *} \\
8.5^{* *} \\
26.7^{* *} \\
6.9^{* *}\end{array}$ \\
\hline
\end{tabular}

Error (b)-For conclusions applicable to varying soil and climatic conditions in Puerto Rico.

Error (c)-For comparisons within a location. Used in last $\mathrm{F}-$ Column. 
There was again a highly significant difference in corn yields for the lime-phosphorus treatment (table 7) as found before for sweet potatoes (table 3 ). The difference between fields again was not significant indicating once more that there was no significant difference in corn yields when the green manure was either mulched or plowed under. This time there was no signicant difference in the crop yield due to species when applied to general conditions in Puerto Rico, but this difference was highly significant for comparisons within a location (table 7). For general conditions in Puerto Rico there was no significant difference in corn yields due to the addition of potassium or to the interactions of lime-phosphorus $\mathrm{x}$ potassium and of species $\mathrm{x}$ potassium but the difference was highly significant for comparisons within a location. For example, the addition of potassium alone to the mulched and hoed field at Mayagüez when inorganic nitrogen was added, at the rate of 250 pounds $\mathrm{NH}_{3}$ to the acre, raised the acre yield of shelled corn from 6.0 to 21 hundredweights and to 35.6 when lime-phosphorus was added. In the field at Mayagüez, where the corresponding green manures were plowed under, there was a significant increase in yield of 25.1 hundredweights of shelled corn, to the acre, only, when the potassium was added with lime and phosphorus. The yield responses indicate that the fields of Catalina clay at Mayagüez were deficient in potash, while those at Río Piedras, of Fajardo clay, had sufficient of this element.

Twenty seven months after the lime and phosphorus were applied (table 8), the mean $\mathrm{pH}$ of the soil for the five treatments including the check, at both fields in Mayagüez was 5.5, while that in Río Piedras was 5.0. The mean $\mathrm{pH}$ for the acid plots was 4.7 at Mayagüez and 4.8 at Río Piedras. The mean organic matter content for all treatments in both fields at Mayagüez was 2.2 per cent and at Río.Piedras was 1.6. The mean nitrogen content at Mayagüez was .19 per cent and at Río Piedras was .16. The mean carbon-nitrogen ratios were 6.8 and 5.8 , respectively. In the lime-phosphorus plots the mean available phosphorus for the five treatments including the check, at Mayagüez, was 13 parts per million of phosphorus $(\mathrm{P})$, and at Río Piedras was 10 . For the acid plots the values were 8 and 9 , respectively. The mean values for nitrates in the lime-phosphorus plots at Mayagüez was 9 parts per million and at Río Piedras was 14 while for the acid plots were 14 and 10, respectively. 
TABLE NO. VIII

CHEMICAL DATA OF SOIL SAMPLES TAKEN TWENTY SEVEN MONTHS AFTER THE LIME AND PHOSPHORUS WERE APPLIED WHEN THE FIRST CORN CROP WAS HARVESTED

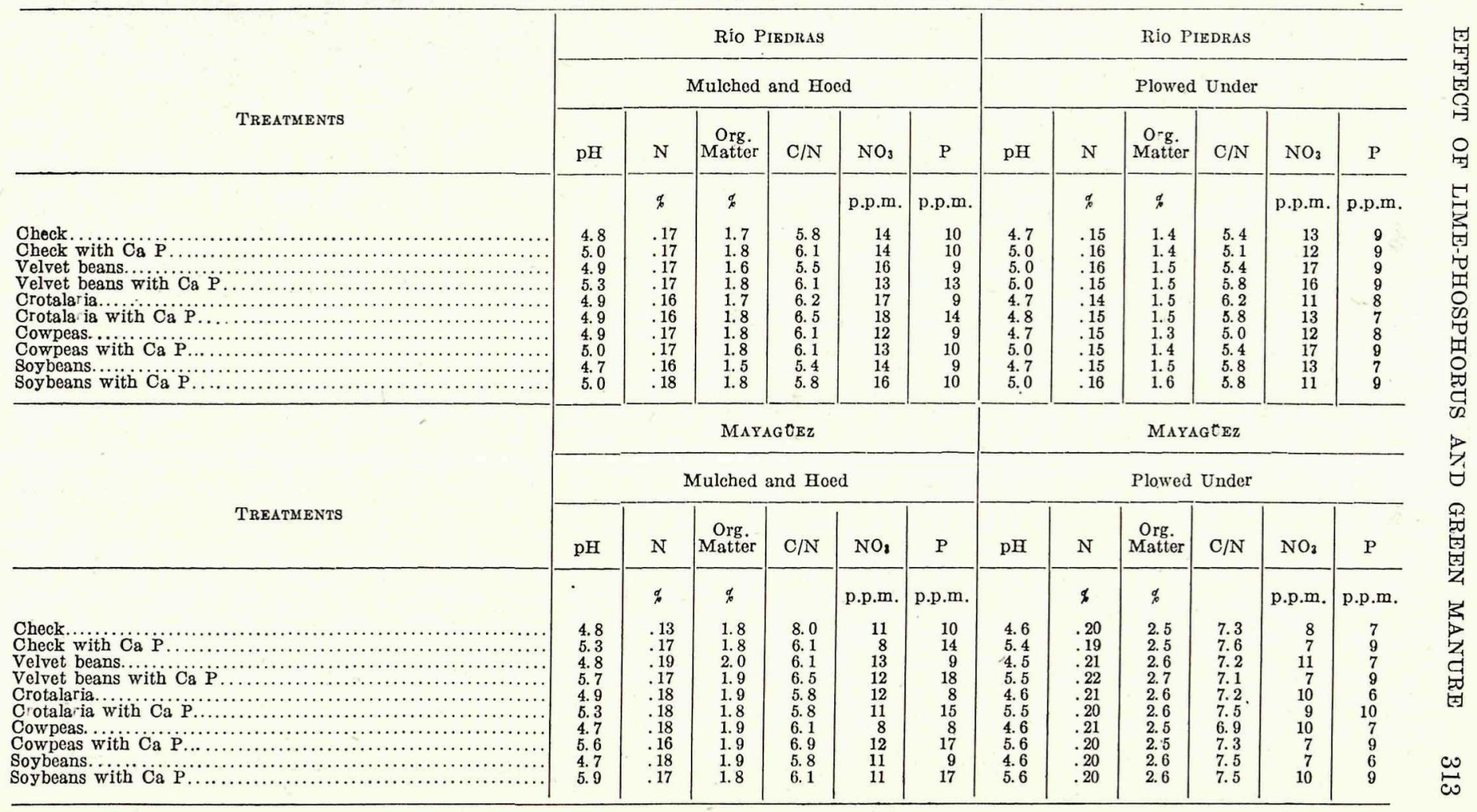


There was no significant difference found between the organic matter contents of the fields at Mayagüez and Río Piedras due to treatments. This indicates that the incorporation of green manure from velvet beans, crotalaria, cowpeas, and soybeans, respectively, plus the trash from one sweet potato and one corn crop, had no effect upon increasing the organic matter content of the soil, in the presence or absence of lime and phosphorus, after a period of twenty seven months.

\section{SUMMARY}

Data are presented here on the efflect that four types of green manure had, on the yields of one sweet potatoes and two corn crops planted in two acid soils of Puerto Rico, in the absence or presence of lime and phosphorus. Comparison is also made as to what effect the green manure had on the crop yields when it was applied as a mulch or when it was plowed under the soil. In the last corn crop, the effect of fertilizing with potash was also studied as well as the effect of adding inorganic nitrogen and potash to the check plots, in the absence or presence of lime and phosphorus. The field experiments were established in Fajardo clay at Río Piedras and in Catalina clay level phase at Mayagüez, located about 75 miles apart.

The green manure sources were from four leguminosae: velvet beans Stizolobium deeringianum; crotalaria Crotalaria striata; cowpeas Vigna sinensis; and soybeans Soja max Otoo$\tan$ variety. The sweet potato used was the Don Juan variety and the corn was the Mayorbela variety, a flinty type.

In general, the leguminosae and the crops responded significantly to lime and phosphorus. Velvet beans gave the highest significant yields of green manure. In general, the velvet beans with lime and phosphorus gave the highest significant yields of sweet potatoes and corn. Cowpeas showed a highly significant detrimental effect in the yield of sweet potatoes. When the green manure was either mulched or plowed under the soil there was no significant difference between the yields of sweet potatoes and corn.

The last corn crop at Mayagüez responded significantly to the application of potash and to the application of potash and inorganic nitrogen specially when lime and phosphorus were added to the checks, but no response was obtained with the green manures. No response to potash in the check and green manure plots were obtained at Río Piedras. 


\section{RESUMEN}

Se estudió el efecto de cuatro tipos de abono verde sobre los rendimientos de una cosecha de batatas y dos de maíz sembradas en dos suelos ácidos de Puerto Rico. También se estudió dicho efecto cuando se encaló el suelo y se le aplicó fósforo así como cuando se dejó el abono verde sobre el terreno o se incorporó ał suelo con arado. En la última cosecha de maíz también se estudió el efecto de abonar con potasa todos los tratamientos y de abonar con nitrógeno inorgánico y potasa las parcelas testigos, con o sin cal y fósforo. Los experimentos de campo se llevaron a cabo en un suelo Fajardo arcilloso en Río Piedras y en un Catalina arcilloso, fase plana, en Mayagüez, a distancias de 75 millas entre ambas localidades.

Los abonos verdes usados fueron de cuatro leguminosas: habas terciopelo, Stizolobium deeringianum; crotalaria Crotalaria striata; fréjoles Vigna sinensis y habas sojas Soja max.

Las leguminosas y las cosechas respondieron significativamente a la cal y el fósforo. Las habas terciopelo dieron el rendimiento más alto de abono verde y cuando se usó cal y fósforo dieron los mejores rendimientos de batatas y maíz. El abono verde de los fréjoles fué detrimental a las batatas.

No hubo diferencia significativa entre los rendimientos de batatas y maíz cuando el abono verde se dejó sobre el suelo o se incorporó con arado.

La última cosecha de maíz en Mayagüez, respondió significativamente a la aplicación de potasa y de nitrógeno inorgánico especialmente cuando se añadió cal y fósforo. No hubo efecto favorable cuando se añadió potasa a los tratamientos de abono verde, en ambos sitios. Tampoco hubo efecto favorable en Río Piedras cuando se añadió potasa y nitrógeno inorgánico, a las parcelas testigos, en la presencia o ausencia de cal y fósforo.

\section{CONCLUSION}

Better yields of sweet potatoes and corn are obtained in the acid soils of Puerto Rico when lime, phosphorus, and velvet beans as a green manure source, are added. Soils deficient in nitrogen and potash require also additional fertilization with nitrogen and potash. 


\section{CONCLUSIÓN}

Mejores rendimientos de batatas y maíz se obtienen en los suelos ácidos de Puerto Rico cuando se aplica cal, fósforo y abono verde derivado de habas terciopelo. Los suelos que están deficientes en nitrógeno y potasio también deben de abonarse con nitrógeno y potasa.

\section{ACKNOWLEDGEMENTS}

The writers wish to express acknowledgement to Mr. Pablo Landrau Jr., (photos 1, 2, 3) who was in charge of the field work at Río Piedras from September 1, 1946 to August 16, 1947, while Mr. Pedro Tirado Sulsona was taking graduate studies in the University of Texas.

The writers wish also to express their appreciation to $\mathrm{Mr}$. Alfonso Riera, Soil Chemist, (photo 4) for doing the nitrogen determinations presented in table 8, and to Dr. B. G. Capó, Assistant Director for Research and Head Agronomy of the Horticulture Department, for his advice in the statistical interpretation of the data.

\section{LITERATURE CITED}

(1) Bonnet, J. A., Telford, E. A., Mariota, F., and Tirado Sulsona, P. Effect of lime and phosphorus on the yield of four leguminosae in two acid soils of Puerto Rico. J. Agric. Univ. P. R. 29 (2): 47-46, 1945.

(2) Wolfe, B. Determination of soluble nutrients in soil and plant extracts by means of a photoelectric colorimeter. Ind. Eng. Chem Anal. Ed. 15: 248, 1943. 


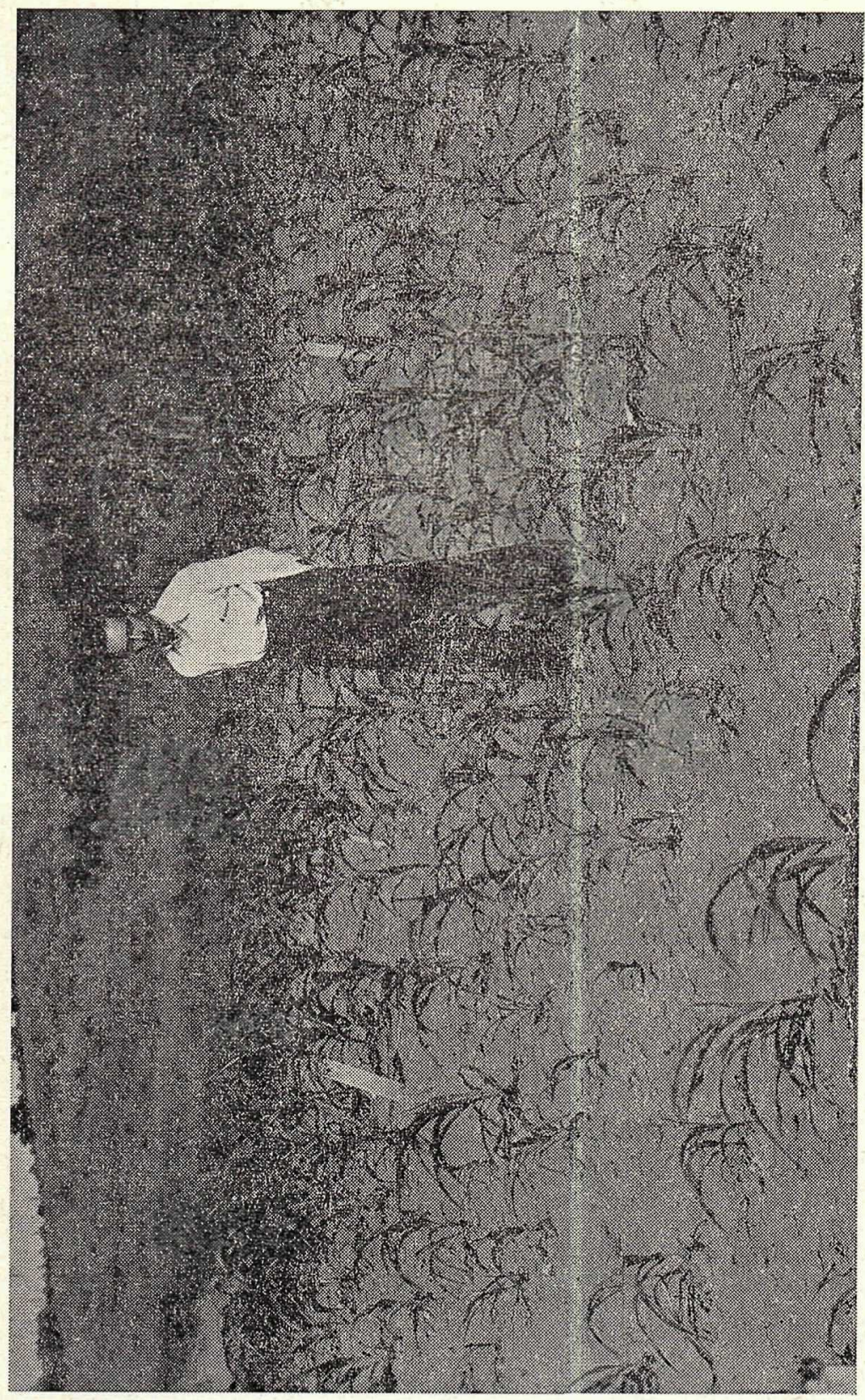

흃

号

E

염

煦

A

율

+)

है

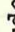

空

.

西

范

कू

뎡

茟

운

연

द

응

密

엄

శ్ర

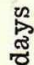

\%

๓

붕

ㅇํㅇ

엄 


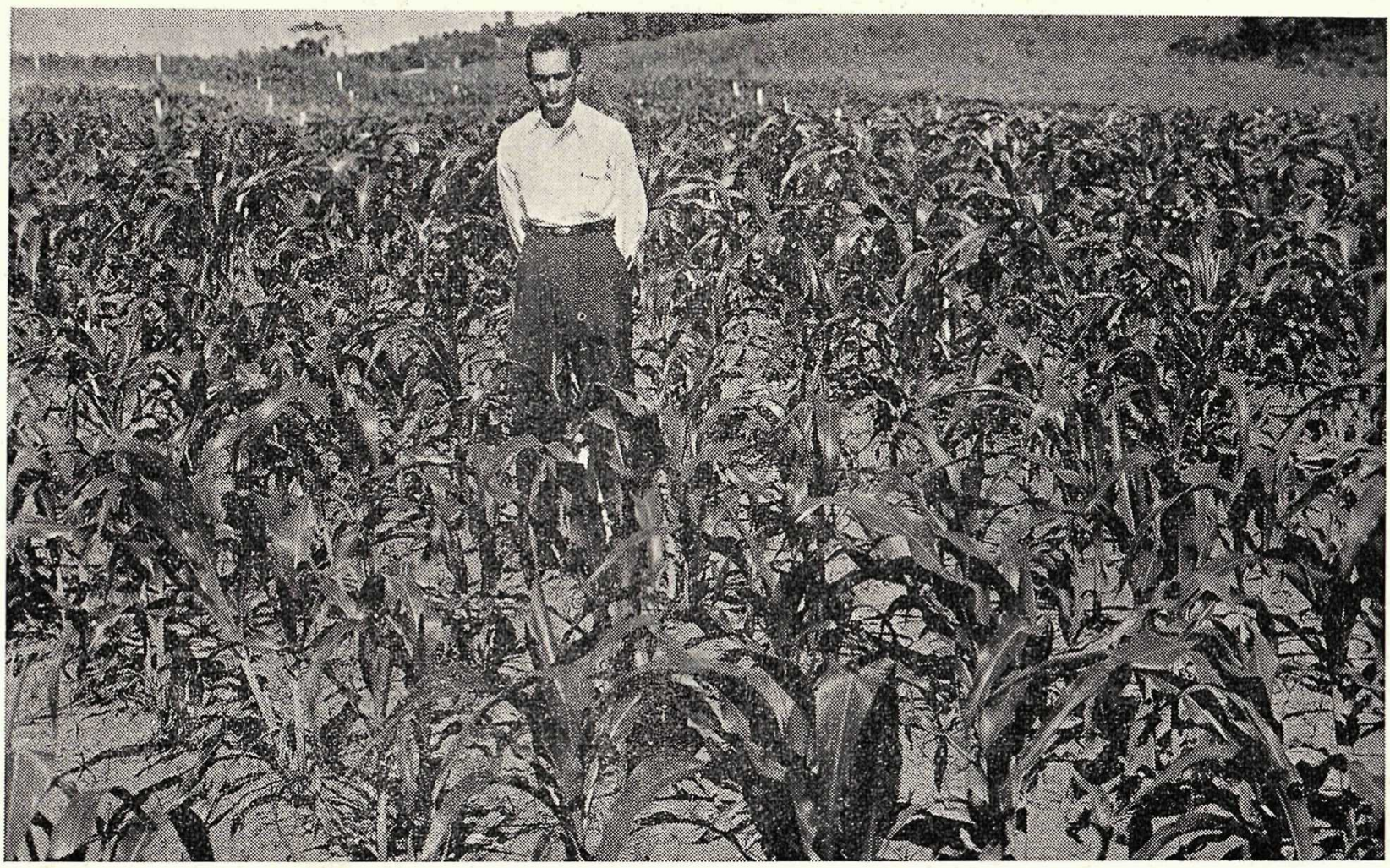

PHOTO 2.-Corn, 33 days old, the sixth crop in the rotabion, grown in Fajardo clay at Río Piedras with lime and phosphorus. 


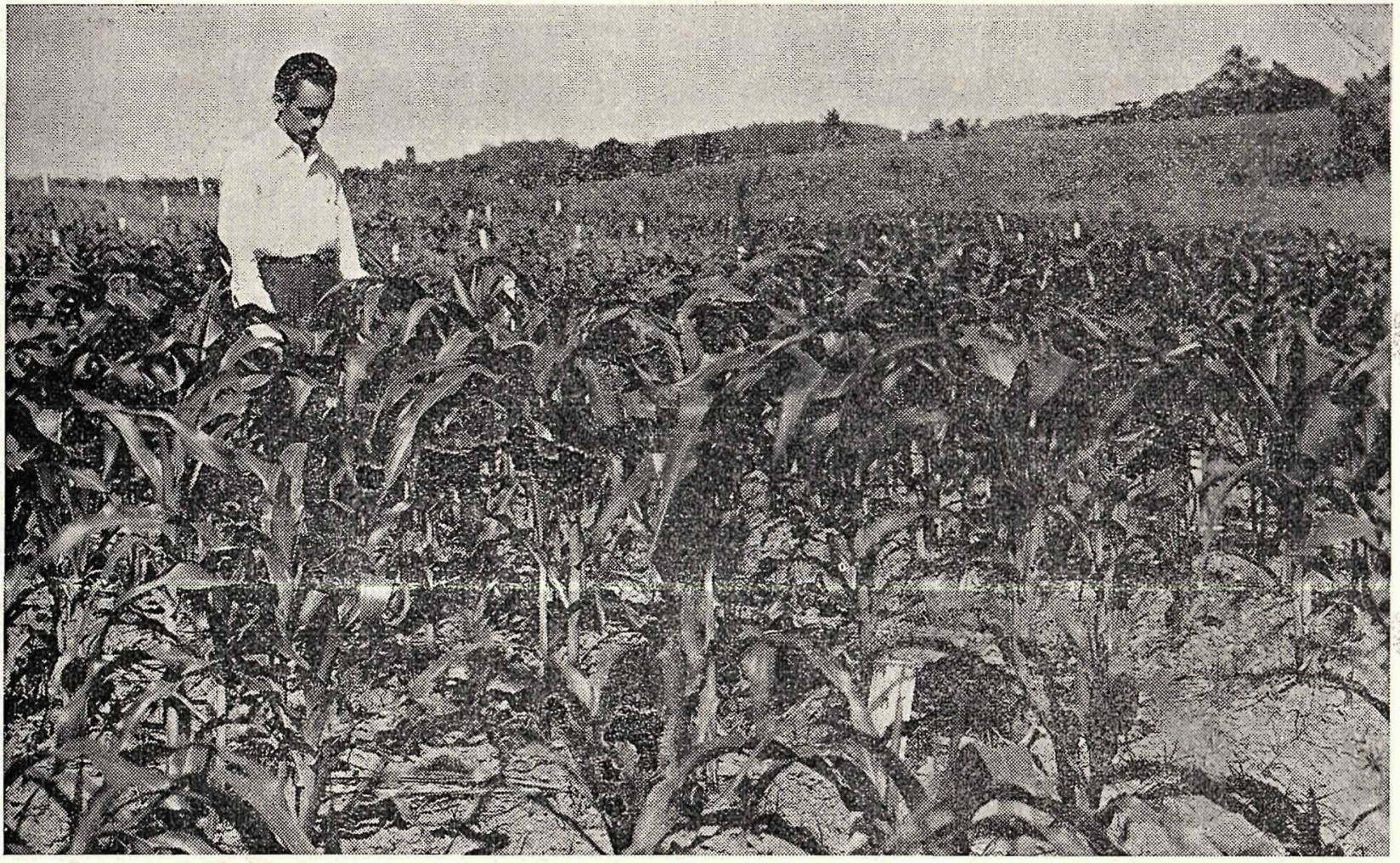

Pното 3.-Corn 33 days old, the sixth crop in the rotation grown in Fajardo člay at Río Piedras with green manure from velvet beans, lime and phosphorus. 


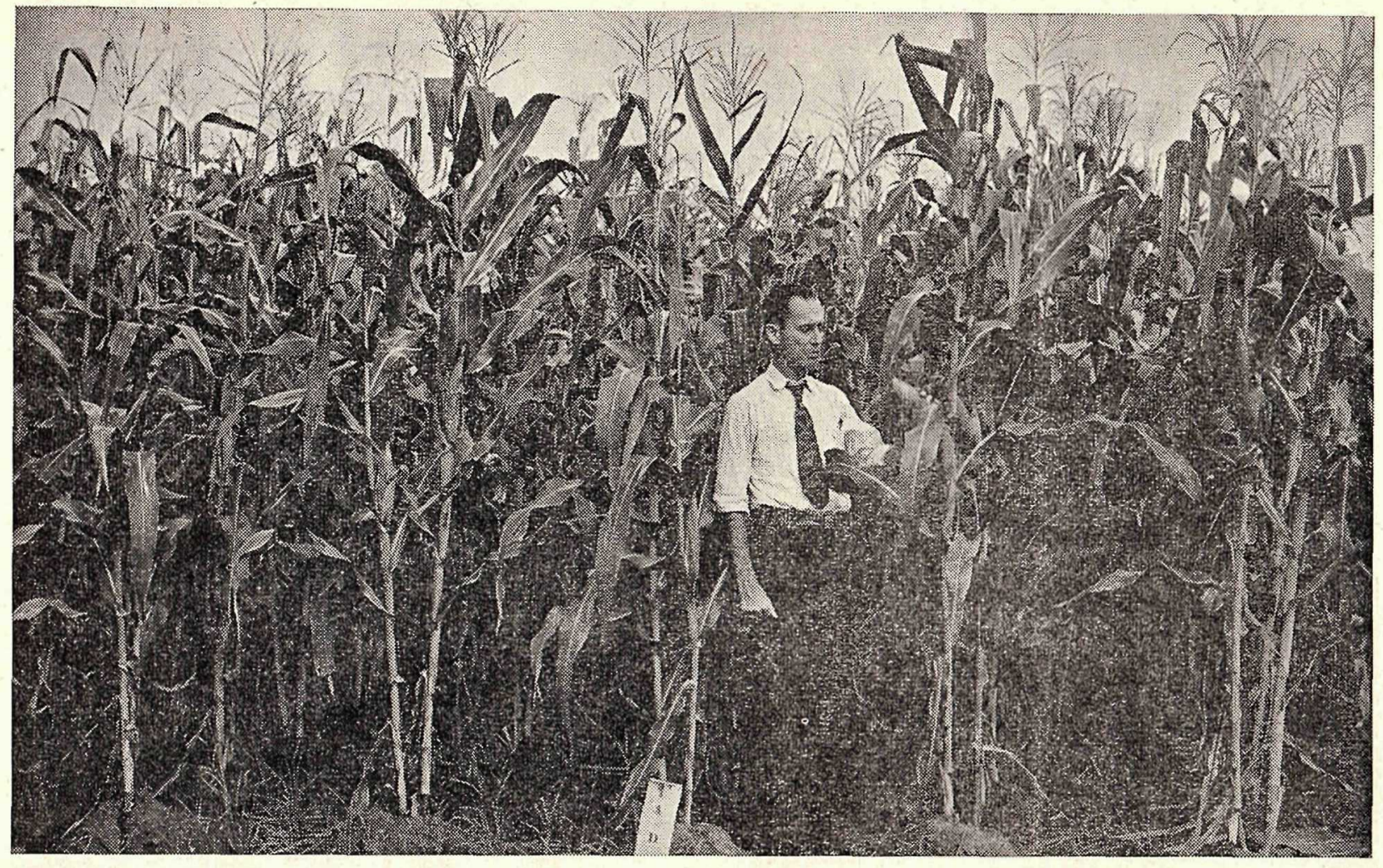

PHоTO 4.-Corn 74 days old, the sixth crop in the rotation, grown in Fajardo clay Río Piedras with green manure from velvet beans, lime and phosphorus. 


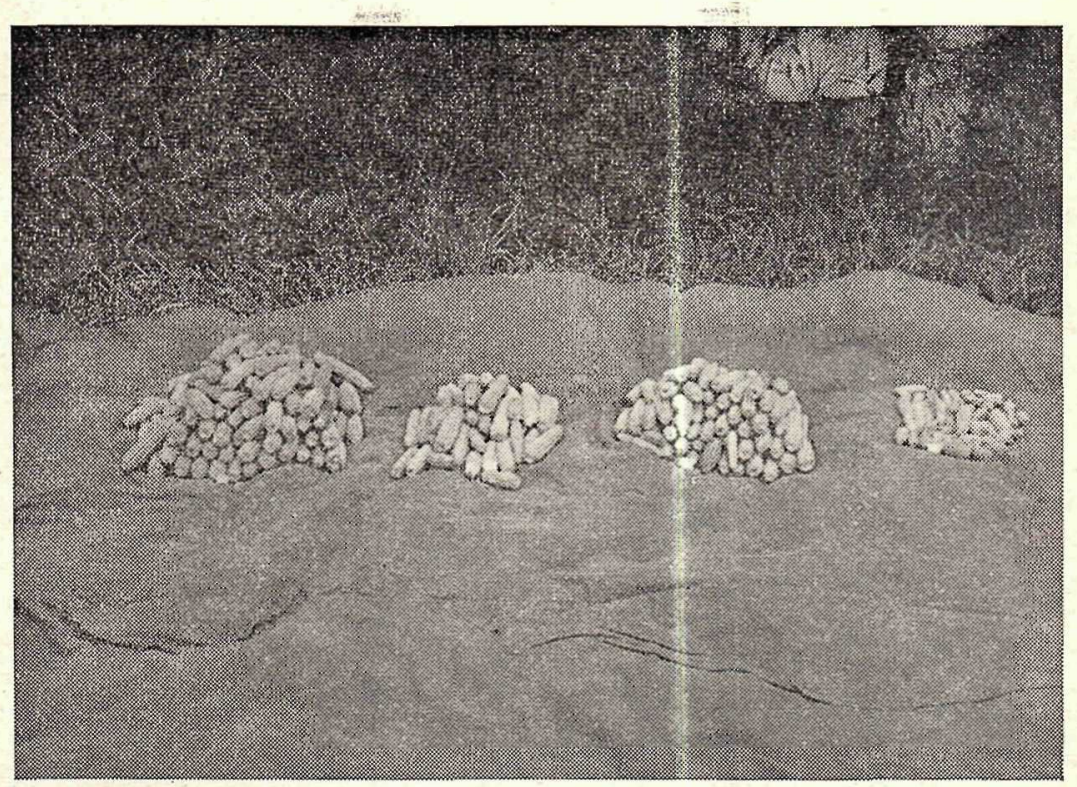

PFITO 5.-Ears of corn harvested at Mayagiez in the sixth crop of the rotation. Counting from right to left:

1. Check

2. Iime-phosphorus

3. Green manure from velvet beans

4. Green manure from velvet beans with lime and phosphorus
3.0 bu. per acre

11. 5 bu. per acre

10.8 bu. per acre

29. 3 bu. per acre 